\title{
Effects of shading on the growth, development and yield of winged bean (Psophocarpus tetragonolobus)
}

\section{Murthazar Naim Raai ${ }^{1}$ Nurul Amalina Mohd Zain ${ }^{1}$ Normaniza Osman $^{1}$ Nur Ardiyana Rejab ${ }^{1}$ Nurul Amylia Sahruzaini ${ }^{1}$ Acga Cheng ${ }^{*}$ iD}

${ }^{1}$ Institute of Biological Sciences, Faculty of Science, University of Malaya, 50603, Kuala Lumpur, Malaysia. Email: acgacheng@um.edu.my. ${ }^{*}$ Corresponding author.

ABSTRACT: An experiment was conducted to investigate the effects of different shading regimes $[$ i.e., $60 \%$ (heavy), 30\% (moderate), and $0 \%$ (control)] on 25 traits associated with the morphological features, photosynthetic gas exchange and agronomic characteristics of winged bean (Psophocarpus tetragonolobus), an underutilized protein-rich legume from the tropics. Collectively, $80 \%$ of the studied variables displayed significant differences $(P<0.05)$ between at least two shade treatments. Shading generally showed most pronounced effect on the physiological traits of the legume, whereby the stomatal conductance, photosynthetic and transpiration rate differed significantly among plants for all treatments. The non-shaded plants were observed to have superior growth and physiological responses than the shaded plants. Interestingly, the moderately shaded plants exhibited the highest yield per plant, which significantly differed from the non-shaded and heavily shaded plants. This indicated that winged bean can adapt to partial canopy cover, making it a potential nitrogen-fixing cash crop which can be planted together with fruit or oil trees in commercial plantations.

Key words: morphology, physiology, shading, winged bean, yield.

Efeitos do sombreamento no crescimento, desenvolvimento e produtividade do feijão alado (Psophocarpus tetragonolobus)

RESUMO: Foi conduzido um experimento para investigar os efeitos de diferentes regimes de sombreamento [60\% (pesado), 30\% (moderado) e $0 \%$ (controle)] em 25 características associadas às características morfológicas, trocas gasosas fotossintéticas e características agronômicas de feijão alado (Psophocarpus tetragonolobus), leguminosa subutilizada rica em proteínas dos trópicos. Coletivamente, $80 \%$ das variáveis estudadas apresentaram diferenças significativas $(P<0,05)$ entre pelo menos dois tratamentos à sombra. O sombreamento mostrou efeito mais pronunciado nas características fisiológicas da leguminosa, pelo que a condutância estomática, a taxa fotossintética e a transpiração diferiram significativamente entre as plantas em todos os tratamentos. Observou-se que as plantas não sombreadas apresentaram crescimento e respostas fisiológicas superiores às plantas sombreadas. Curiosamente, as plantas moderadamente sombreadas exibiram o maior rendimento por planta, que diferiu significativamente das plantas não sombreadas e fortemente das sombreadas. Isso indica que o feijão alado pode se adaptar a cobertura parcial do dossel, tornando-o uma cultura potencial de fixação de nitrogênio que pode ser plantada em conjunto com árvores frutíferas ou oleaginosas em plantações comerciais.

Palavras-chave: morfologia, fisiologia, sombreamento, feijão alado, produtividade.

\section{INTRODUCTION}

In recent years, global research on underutilized crops has continued to flourish following the call to action to promote sustainable agriculture through crop diversification (MASSAWE et al., 2016). The development of underutilized protein-rich legumes is one of the several momentous solutions in addressing the impending protein shortages and food crisis around the world, especially in the developing countries where high-protein sources like meat and grains are scarce and expensive
(CHENG et al., 2019). Winged bean (Psophocarpus tetragonolobus), for example, is a promising future crop in the tropics owing to its hardiness and high protein content (MOHANTY et al., 2013; MASSAWE et al. 2016; CHENG et al., 2019). Native to Papua New Guinea, this diploid species from the Fabaceae (or Leguminosae) family is grown mainly by subsistence farmers in its native home and many hot and humid countries, particularly those in South and Southeast Asia. This self-fertilizing leguminous plant has multipurpose uses as human food, livestock feed, and environmental conservation (PEYACHOKNAGUL et 
al., 1989; HARDER \& SMARTT, 1992). The protein content of winged bean is equivalent to that of soybeans (32-38\%), which is about $50 \%$ higher than most of the other edible legumes (NRC, 1975; AMOO et al. 2006). Additionally, its seeds contain a good balance of amino acids, including lysine, making them an excellent complement for cereal-based diets typically deficient in lysine (SHURTLEFF \& AOYAGI, 1979).

Like other leguminous crops, the winged bean has the ability to fix atmospheric nitrogen, which consequently increases soil fertility and production of other crops such as rice (RAHMAN et al., 2014). It is a potential cash crop in the tropics as its cultivation requires low external inputs (MASSAWE et al., 2016). However, the winged bean has not been planted on a large scale due in part to its relatively low yield potential (MOHANTY et al., 2013). One of the most challenging aspects of winged bean cultivation is the management of its vigorous vining and indeterminate growth habits (STEPHENSON et al., 1981; WONG et al., 2015). Although, studies on winged bean's growth and development flourished briefly during the $1970 \mathrm{~s}$ and $1980 \mathrm{~s}$ (STEPHENSON et al., 1981), some of the reported findings remain largely inconclusive (WONG et al., 2015).

In general, plant growth and development are influenced by both genetic (endogenous) and environmental (exogenous) factors. While the genetic factor usually determines certain physical features of a plant, the expression of genes is often influenced by environment (BROWN et al., 2014). Studies have been carried out to examine major exogenous factors such as light and temperature on the growth and development of some leguminous species, including the chickpeas (Cicer arietinum) and soybeans (Glycine max) (BAHAYI \& REZGUI, 2015; VAN ROEKEL et al., 2015). Nevertheless, this is not the case for the winged bean. The utilization of this versatile and high-protein legume is relatively low, and the existing knowledge on its growth patterns under different environmental conditions remains limited. A concerted effort to better understand the relationships between the morpho-physiological responses of this legume with relevant exogenous factors is; therefore, required in providing a more in-depth insight into its growth patterns, and subsequently paving the way for the breeding of self-supporting and improved winged bean cultivars (VATANPARAST et al., 2016; TANZI et al., 2019). The objectives of this study were to examine the effects of different shading levels on the morphological features, photosynthetic gas exchange and agronomic characteristics of winged bean, and to determine the optimum shading regime for this legume.

\section{MATERIALS AND METHODS}

\section{Plant material and experimental design}

Seeds of winged bean accession S319 from Sri Lanka were germinated and uniform seedlings were grown at Rimba Ilmu Botanical Gardens, University of Malaya $\left(3.13^{\circ} \mathrm{N}, 101.66^{\circ} \mathrm{E}\right)$ between December 2017 and April 2018. The experiment was conducted using a completely randomized design; with the spacing of $60 \mathrm{~cm}$ between plants and 100 $\mathrm{cm}$ between rows. For sixteen weeks in each season, 18 plants were grown under each shading treatment: $60 \%$ black nylon shade net (heavy shade), 30\% black nylon shade net (moderate shade), and without shade (control). For each treatment, data from seven healthy plants were used to evaluate 25 traits selected in the present study (Table 1). Throughout the growing period, all plants were irrigated daily and fertilizers were applied twice a month. The average recorded relative humidity and air temperature at the experimental plots were $80 \%$ and $32{ }^{\circ} \mathrm{C}$, respectively.

\section{Evaluation of morphological and yield parameters}

All linear measurements were obtained using a measuring tape with an accuracy of $\pm 1 \mathrm{~mm}$. Measurements for plant height $(\mathrm{PH})$ were taken on the main stem from the soil reference point to the top nodal region, while $7^{\text {th }}$ internode length $(\mathrm{InL})$ was taken at the 7 th internode from the soil reference point. Number of nodes, leaves, and branches per plant (NoN, NoL, and NoB, respectively) were recorded on weekly basis up to $9^{\text {th }}$ weeks. Days to flowering (DTF) was the number of days recorded from germination to first flowering. All analyses were made in triplicate.

On the $16^{\text {th }}$ week, winged bean plants with their pods from each treatment were harvested and oven-dried at $65{ }^{\circ} \mathrm{C}$ for $72 \mathrm{~h}$ to measure yield-related traits such as pods per plant (NoP), seed diameter (SD), and hundred-seed weight (HSW). The number of seeds per pod (NoS), pod diameter (PodD), pod length (PodL), and pod width (PodW) were recorded using five dried pods. The weight of harvested seeds per plant was measured to obtain the yield per plant (YPP). The total aboveground plant biomass was recorded as the average aboveground biomass of five dried plants, while the harvest index (HI) was calculated as the ratio of harvested seeds mass to the total aboveground plant biomass.

\section{Evaluation of physiological parameters \\ In-situ chlorophyll (SPAD) was measured} using SPAD-502 (Minolta, Japan) on the $3^{\text {rd }}, 6^{\text {th }}, 9^{\text {th }}$, and $12^{\text {th }}$ weeks. The LI-6400XT Portable Photosynthesis 
System (LI-COR, USA) was used to determine photosynthetic gas exchange parameters, including photosynthetic rate $(A)$, stomatal conductance $\left(\mathrm{g}_{\mathrm{s}}\right)$, internal $\mathrm{CO}_{2}$ concentration $\left(\mathrm{C}_{\mathrm{i}}\right)$, and transpiration rate (E). The physiological measurements were taken under standard conditions [i.e. leaf temperature of $30{ }^{\circ} \mathrm{C}$, PAR of $1,200 \mu \mathrm{mol} \mathrm{m} \mathrm{m}^{-2} \mathrm{~s}^{-1}$, and adjusted $\mathrm{CO}_{2}$ flux at $400 \mu \mathrm{mol} \mathrm{s}^{-1}$ inside the chamber] between the $7^{\text {th }}$ and the $8^{\text {th }}$ week on three individual plants; three leaves for each plant from each shading treatment between $1000 \mathrm{~h}$ and $1400 \mathrm{~h}$.

\section{Evaluation of assimilation pigments and crude protein content}

Upon completion of yield analysis, concentrations of assimilation pigments, including chlorophyll A (ChlA) and chlorophyll B (ChlB), and carotenoids (Car), were determined following the methods by SUMANTA et al. (2014) with minor modifications. Concentrations of ChlA, ChlB, and Car were measured based on the wavelengths of the spectral absorbance, i.e., $663.2 \mathrm{~nm}, 646.8 \mathrm{~nm}$ and $470.0 \mathrm{~nm}$, respectively. Additionally, the crude protein content of both winged bean seed (ProteinS) and leaf (ProteinL) was also being determined using the modified Kjeldahl method (AOAC, 1980). All analyses were made in triplicate.

\section{Statistical analysis}

The recorded data were subjected to descriptive statistics and one-way analysis of variance (ANOVA) with Tukey's honestly significant difference (HSD) post hoc test, and the Pearson's correlation was used to explore the relationships among variables. Simple linear regression was also used to examine the highly significant pairwise correlations. All analyses were performed using the SPSS Statistics Software (Version 25).

\section{RESULTS AND DISCUSSION}

We reported here, for the first time, the effects of different intensities of shades towards the growth, development, and yield of winged bean.

Table 1 - Morphological features, photosynthetic gas exchange and agronomic parameters of winged bean plants subjected to varied shading regimes.

\begin{tabular}{|c|c|c|c|c|}
\hline 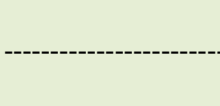 & - & $\begin{array}{c}\text { Non-shaded } \\
\text { Plants (Control) }\end{array}$ & $\begin{array}{l}\text { Moderately } \\
\text { shaded plants } \\
(30 \% \text { shade })\end{array}$ & $\begin{array}{l}\text { Heavily shaded plants } \\
(60 \% \text { shade })\end{array}$ \\
\hline \multirow[t]{6}{*}{ Growth } & $\mathrm{PH}(\mathrm{cm})$ & $374.9 \pm 15.61^{\mathrm{a}}$ & $333.0 \pm 3.83^{b}$ & $290.2 \pm 3.93^{c}$ \\
\hline & NoB & $47.9 \pm 3.10^{\mathrm{a}}$ & $35.7 \pm 0.81^{\mathrm{b}}$ & $33.6 \pm 2.44^{b}$ \\
\hline & NoL & $104.0 \pm 7.06^{\mathrm{a}}$ & $90.9 \pm 1.69^{b}$ & $76.0 \pm 2.67^{\mathrm{c}}$ \\
\hline & NoN & $16.6 \pm 0.94^{\mathrm{a}}$ & $15.4 \pm 0.78^{\mathrm{ab}}$ & $13.6 \pm 0.38^{b}$ \\
\hline & $\operatorname{InL}(\mathrm{cm})$ & $14.3 \pm 0.13^{\mathrm{a}}$ & $12.0 \pm 0.45^{b}$ & $10.9 \pm 0.46^{b}$ \\
\hline & DTF & $48.9 \pm 2.28^{\mathrm{a}}$ & $63.9 \pm 0.34^{b}$ & $67.1 \pm 0.56^{\mathrm{c}}$ \\
\hline \multirow[t]{9}{*}{ Yield } & NoP & $7.7 \pm 0.36^{b}$ & $10.3 \pm 0.57^{\mathrm{a}}$ & $7.6 \pm 0.53^{b}$ \\
\hline & PodD $(\mathrm{cm})$ & $9.4 \pm 0.88^{\mathrm{a}}$ & $9.9 \pm 0.91^{\mathrm{a}}$ & $8.0 \pm 0.61^{\mathrm{a}}$ \\
\hline & PodL (cm) & $18.5 \pm 1.70^{b}$ & $26.9 \pm 2.46^{\mathrm{a}}$ & $17.1 \pm 2.36^{b}$ \\
\hline & PodW (g) & $6.3 \pm 0.79^{\mathrm{ab}}$ & $7.5 \pm 0.43^{\mathrm{a}}$ & $5.3 \pm 0.97^{b}$ \\
\hline & NoS & $10.6 \pm 1.34^{b}$ & $13.5 \pm 0.63^{\mathrm{a}}$ & $8.9 \pm 1.41^{b}$ \\
\hline & $\mathrm{SD}(\mathrm{cm})$ & $0.8 \pm 0.11^{\mathrm{ab}}$ & $1.0 \pm 0.03^{\mathrm{a}}$ & $0.7 \pm 0.08^{b}$ \\
\hline & HSW (g) & $20.8 \pm 0.05^{b}$ & $25.0 \pm 0.05^{\mathrm{a}}$ & $19.6 \pm 0.08^{b}$ \\
\hline & YPP (g) & $23.8 \pm 1.06^{\mathrm{b}}$ & $28.9 \pm 1.47^{\mathrm{a}}$ & $21.4 \pm 1.48^{b}$ \\
\hline & HI & $0.2 \pm 0.03^{a b}$ & $0.3 \pm 0.02^{a}$ & $0.2 \pm 0.02^{b}$ \\
\hline In-situ chlorophyll & SPAD & $36.17 \pm 0.65^{\mathrm{a}}$ & $28.18 \pm 2.18^{a b}$ & $25.03 \pm 2.00^{\mathrm{b}}$ \\
\hline \multirow[t]{4}{*}{ Pigments } & ChlA (ug/mL) & $9.5 \pm 1.06^{\mathrm{a}}$ & $13.0 \pm 2.22^{a}$ & $9.6 \pm 1.87^{\mathrm{a}}$ \\
\hline & ChlB (ug/mL) & $13.3 \pm 0.92^{\mathrm{a}}$ & $13.6 \pm 3.13^{\mathrm{a}}$ & $15.0 \pm 1.81^{\mathrm{a}}$ \\
\hline & Car (ug/mL) & $0.66 \pm 0.06^{\mathrm{a}}$ & $0.92 \pm 0.09^{\mathrm{a}}$ & $0.98 \pm 0.10^{\mathrm{a}}$ \\
\hline & ProteinL (\%) & $15.8 \pm 0.28^{b}$ & $17.6 \pm 0.30^{\mathrm{a}}$ & $14.6 \pm 0.25^{c}$ \\
\hline Protein content & ProteinS (\%) & $31.7 \pm 3.88^{a b}$ & $35.4 \pm 1.04^{\mathrm{a}}$ & $23.2 \pm 1.86^{b}$ \\
\hline
\end{tabular}

Means followed by the same letter within rows do not differ significantly between shade treatments $(P>0.05)$.

Ciência Rural, v.50, n.2, 2020. 
Table 1 shows that all the studied variables, with the exception of PodD, Ci, ChlA, ChlB, and Car, displayed significant differences between at least two of the light treatments $(\mathrm{P}<0.05)$.

Based on the morphological parameters tested in this study, winged bean plants revealed greater growth responses towards non-shaded condition (Table 1). Non-shaded plants had higher PH, DTF, NoB, NoL, and InL $(\mathrm{P}<0.05)$ than both the moderately shaded and heavy shaded plants, indicating that winged bean has an optimum growth without shade. This outcome is consistent with the studies conducted on other legumes such as chickpea (LAKE \& SADRAS, 2014) and soybean (IQBAL et al., 2018). The non-shaded plants in this study were taller and took a shorter period to flower than the moderately shaded and heavily shaded plants (Table 1), supporting the preliminary conclusion made by HERATH \& ORMROD (1979) that flowering in winged bean could be delayed by low light intensity. Interestingly, the yield of the moderately shaded plants was generally higher than both the non- shaded and heavily shaded plants (Table 1). Moderately shaded plants also recorded higher NoP, PodL, NoS, and HSW $(\mathrm{P}<0.05)$ than the non-shaded and heavily shaded plants (Table 1). This can perhaps be explained using the recent findings from a study conducted by KHALID et al., (2019) on soybean. They reported that plants grown under light shading could yield better because the stomata of these plants may perform more optimally during the physiological processes, besides the possibility of increased availability of primary bioactive compounds for their seed formation. The heavily shaded plants; conversely, exhibited the lowest yields with the shortest plant stature (Table 1). These results indicated that heavy shading adversely affects the yield of winged bean, just as shown in many other crop plants, such as soybean and sage (Salvia officinalis) (ZERVOUDAKIS et al., 2012; WU et al., 2016; IQBAL et al., 2018).

The non-shaded plants showed higher physiological responses than the shaded plants, recording greater values for $A, g_{s}$ and $E(P<0.05)$ (Figure 1). The rate of photosynthesis in non-shaded

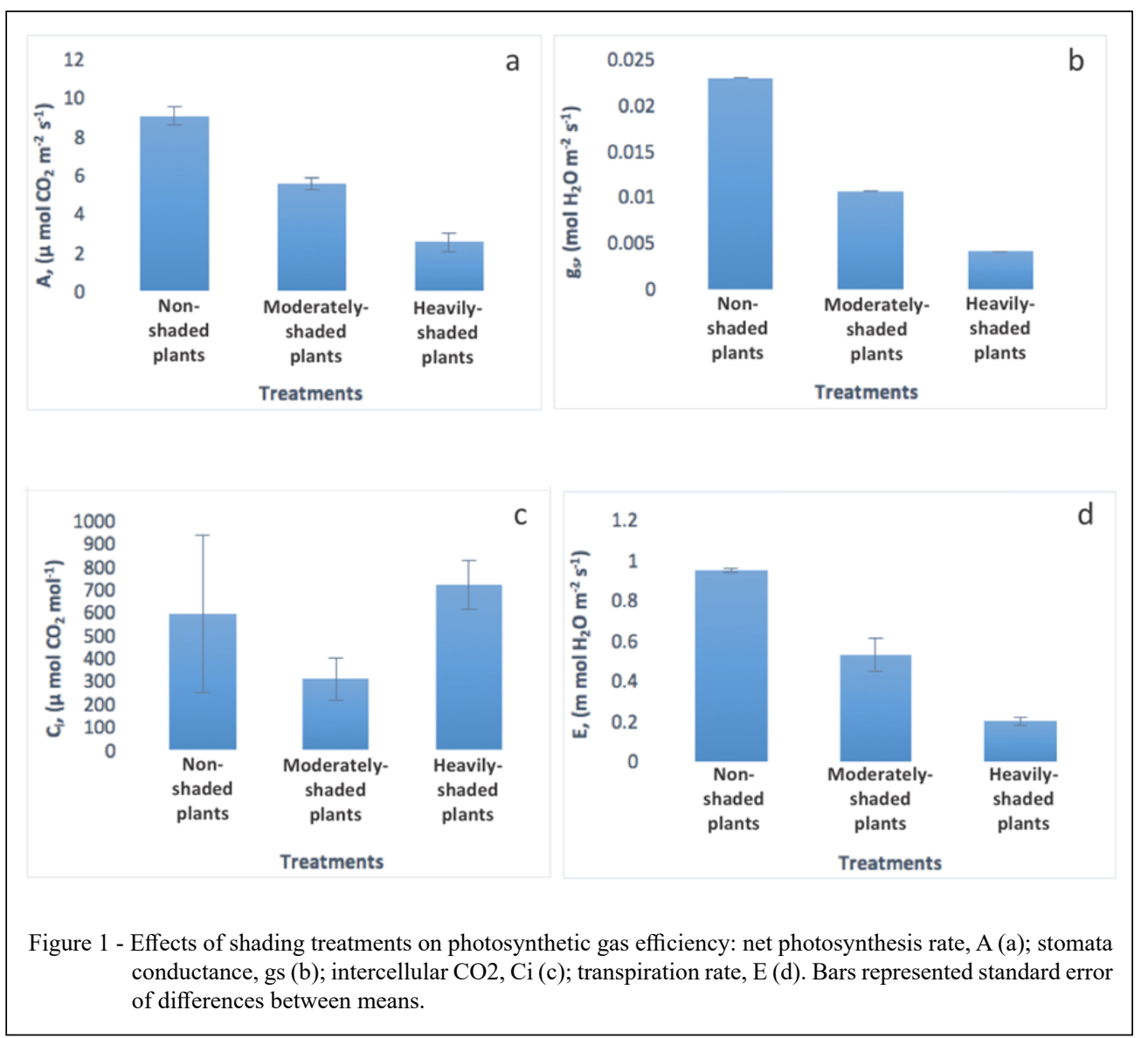

Ciência Rural, v.50, n.2, 2020. 
plants was between two and four times higher than moderately shaded and heavily shaded plants, respectively (Figure 1). This outcome is expected given that the rate of photosynthesis in most plants will increase if the light availability or intensity increases (ATHANASIOU et al., 2010; ZHU et al., 2017). This notion; however, can only be applied to cases where other major limiting factors, including carbon dioxide concentration and temperature, are negligible (KAISER et al., 2014). Regression analysis showed that A had significantly increased PH $\left(\mathrm{r}^{2}=0.6449^{* *}\right)$ and $\operatorname{NoL}\left(r^{2}=0.6012^{* *}\right)$ of winged bean (Figure 2$)$, displaying the strength of source and sink relationship with the increasing of photosynthesis rate. The results are in agreements with studies on some other plant species such as neorotropical species (RIJKERS et al., 2000) and dipterocarp species (KENZO et al., 2006).

As for the concentrations of assimilation pigments, there were no statistically significant differences $(\mathrm{P}>0.05)$ between plants grown under all shading treatments for ChlA, ChlB, and Car. Additionally, the in-situ chlorophyll showed nonsignificant differences among treatments. These results suggested that winged bean is capable of adjusting their photosynthetic mechanism to accommodate different levels of light. Several studies on algae species, including kleptoplastic benthic foraminifer (Haynesina germanica) (JAUFFRAIS et al., 2017) and red seaweed (Pyropia haitanensis) (WU, 2016) also found that there were no significant differences of pigment contents when the algae were grown in various light conditions.

Nevertheless, shading was reported to affect the protein content of winged bean, both on its leaves and seeds (Table 1). Moderately shaded plants recorded the highest Protein S $(35.4 \% \pm 1.04)$, which was similar to the non-shaded plants $(31.7 \% \pm 3.88)$ but much higher $(\mathrm{P}<0.05)$ than the heavily shaded plants $(23.2 \% \pm 1.86)$. This is a good indication that winged bean plants are well-suited to be grown under tree canopies in commercial plantations as secondary or cash crops which is high in protein. Winged bean has recently been promoted as one of the potential crops for the future due mainly to its exceptionally high protein content (CHENG et al., 2019). Being a nitrogen-fixing plant, winged bean has a symbiotic relationship with the motile bacteria rhizobia which can help to replenish the soil (SOMASEGARAN \& HOBEN, 2012). Monoculture tree plantation has long been a prime issue in the tropical regions (PUTZ \& REDFORD, 2010). As such, planting cash crops like winged bean which can supply natural nitrogen fertilizer together with these trees may benefit both the plantation company and the environment. Nonetheless, it should be noted that the winged bean seeds obtained from heavy shading condition in

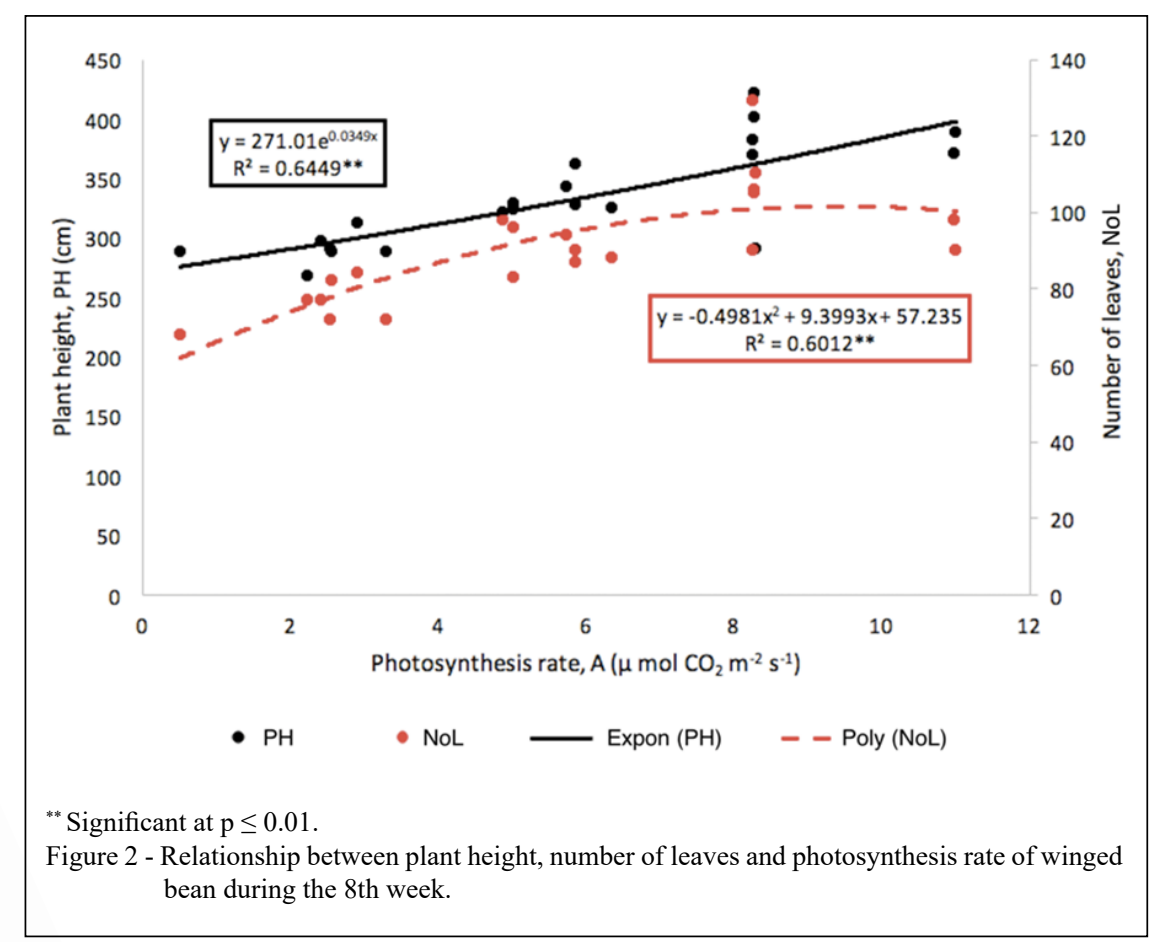

Ciência Rural, v.50, n.2, 2020. 
this study recorded only about $70 \%$ of the ProteinS produced by those under light shading. This implied that winged bean is not a suitable cash crop for plantations with a high percentage of canopy cover.

\section{CONCLUSION}

Winged bean, being hailed as a new soybean of the tropics, has the potential to become one of the affordable plant-based protein sources in the near future and its improvement is therefore crucial. Based on our overall finding, light does play a crucial role in the growth and development of winged bean. The outcomes of the present study, for the most part, demonstrated that winged bean grows well and yields better under light shading condition. The release of this new insight can benefit the producers, consumers, as well as the environment. Further research is recommended to assess the crop's response to other important exogenous factors such as temperature and water availability.

\section{ACNOWLEDGEMENTS}

The authors would like to thank Dr. Ahmad Faris Mohd Adnan and two undergraduate students (Mr. Hor Dick Zher and Ms. Fira Syafiqah Saiful Rahim) from the University of Malaya for their support in the data collection stage. The authors would also like to thank the University of Nottingham (Malaysia Campus) for providing the seeds of $P$. tetragonolobus. This work was supported by the Ministry of Education, Malaysia under Grant FP018-2018A and the University of Malaya under Grant BK070-2017.

\section{DECLARATION OF CONFLICT OF} INTERESTS

The authors declare no conflict of interest. The founding sponsors had no role in the design of the study; in the collection, analyses, or interpretation of data; in the writing of the manuscript, and in the decision to publish the results.

\section{AUTHORS' CONTRIBUTIONS}

Conceptualization, A.C.; data curation, N.A.M.Z and N.O.; methodology, N.A.M.Z, N.O. and A.C.; Formal analysis, M.N.R. and N.A.S.; investigation, M.N.R. and N.A.S.; resources, A.C.; software, N.A.M.Z; validation, N.A.M.Z. and N.O.; writing — original draft, M.N.R. and N.A.S.; writing-review \& editing, N.A.M.Z., N.O., and A.C.; supervision, N.A.M.Z. and A.C.; project administration, A.C.; funding acquisition, A.C.

\section{REFERENCES}

AMOO, I. et al. Chemical evaluation of winged beans (Psophocarpus tetragonolobus), pitanga cherries (Eugenia uniflora) and orchid fruit (Orchid fruit myristica). African Journal of Food, Agriculture, Nutrition and Development, v.6, p.17-29,
2006. Available from: <https://www.ajol.info/index.php/ajfand/ article/view/71734/60693>. Accessed: Sep. 25, 2018.

AOAC. Official methods of analysis. Washington DC: Association of Official Analytical Chemists, 1980.

ATHANASIOU, K. et al. Dynamic acclimation of photosynthesis increases plant fitness in changing environments. Plant Physiology, v.152, p.366-373, 2010. Available from: <http://www.plantphysiol. org/content/152/1/366>. Accessed: Aug. 31, 2018. doi: 10.1104/ pp.109.149351.

BAHAYI, K.; REZGUI, S. Agro-morphological characterization and genetic study of new improved lines and cultivars of chickpea (Cicer arietinum L.). Journal of Plant Breeding and Genetics, v.3, p.59-65, 2015. Available from: $<$ https://escijournals.net/index. php/JPBG/article/view/1105/675>. Accessed: Sep. 25, 2018.

BROWN, T. B. et al. TraitCapture: genomic and environment modelling of plant phenomic data. Current Opinion in Plant Biology, v.18, p.73-79, 2014. Available from: $<$ https://www.sciencedirect.com/science/article/pii/ S1369526614000181?via\%3D ihub>. Accessed: Nov. 14, 2018. doi: 10.1016/j.pbi.2014.02.002.

CHENG, A. et al. In search of alternative proteins: unlocking the potential of underutilized tropical legumes. Food Security, v.11, p.1205-1215, 2019. Available from: <https://link.springer.com/ article/10.1007/s12571-019-00977-0>. Accessed: Oct. 30, 2019. doi: 10.1007/s12571-019-00977-0.

HARDER, D. K.; SMARTT, J. Further evidence on the origin of the cultivated winged bean, Psophocarpus tetragonolobus (L.) DC. (Fabaceae): Chromosome numbers and the presence of a host-specific fungus. Economic Botany, v.46, p.187-191, 1992. Available from: <https://www.jstor.org/stable/4255428>. Accessed: Sep. 25, 2018.

HERATH, H. M. W.; ORMROD, D. P. Effects of temperature and photoperiod on winged beans (Psophocarpus tetragonolobus). Annals of Botany, v.43(6), p.729-736, 1979. Available from: $<$ https://academic.oup.com/aob/article-abstract/43/6/729/188019? redirectedFrom=fulltext $>$. Accessed: Aug. 31, 2018. doi: 10.1093/ oxfordjournals.aob.a085686.

IQBAL, N. et al. Comparative analysis of maize-soybean strip intercropping systems: a review. Plant Production Science, p.112, 2018. Available from: <https:/www.tandfonline.com/doi/full/ 10.1080/1343943X.2018.1541137>. Accessed: Feb. 19, 2019. doi: $10.1080 / 1343943 X .2018 .1541137$.

JAUFFRAIS, T. et al. Functional xanthophyll cycle and pigment content of a kleptoplastic benthic foraminifer: Haynesina germanica. PloS One, v.12, e0172678, 2017. Available from: $<$ https://journals.plos.org/plosone/article?id=10.1371/journal. pone.0172678>. Accessed: Dec. 2, 2018. doi: 10.1371/journal. pone. 0172678 .

KAISER, E. et al. Dynamic photosynthesis in different environmental conditions. Journal of Experimental Botany, v.66, p.2415-2426, 2014. Available from: <https://academic.oup. com/jxb/article/66/9/2415/676023>. Accessed: Nov. 14, 2018. doi: $10.1093 / \mathrm{jxb} / \mathrm{eru} 406$.

KENZO, T. et al. Changes in photosynthesis and leaf characteristics with tree height in five dipterocarp species in a tropical rain forest. 
Tree Physiology, v.26, p.865-873, 2006. Available from: <https:// academic.oup.com/treephys/article/26/7/865/1644090>. Accessed: Nov. 14, 2018. doi: 10.1093/treephys/26.7.865.

KHALID, M. et al. Effect of shade treatments on morphology, photosynthesis and chlorophyll flurosense characteristic of soybeans. Applied Ecology and Environmental Research, v.17, p.25512569, 2019. Available from: <http://aloki.hu/pdf/1702_25512569. pdf>. Accessed: Apr. 22, 2019. doi: 10.15666/aeer/1702_25512569.

LAKE, L:; SADRAS, V. O. The critical period for yield determination in chickpea (Cicer arietinum L.). Field Crop Research, v.168, p.1-7, 2014. Available from: <https://www. sciencedirect.com/science/article/pii/S0378429014002287>. Accessed: Apr. 22, 2019.

MASSAWE, F. et al. Crop diversity: an unexploited treasure trove for food security. Trends in Plant Science, v.21(5), p.365-368, 2016. Available from: <https://linkinghub.elsevier.com/retrieve/ pii/S1360-1385(16)00060-1>. Accessed: Feb. 19, 2019. doi: 10.1016/j.tplants.2016.02.006.

MOHANTY, C. S. et al. Characterization of winged bean (Psophocarpus tetragonolobus (L.) DC) based on molecular, chemical and physiological parameters. American Journal of Molecular Biology, v.3, p.187-197, 2013. Available from: $<\mathrm{https} / /$ www.scirp.org/Journal/PaperInformation.aspx?PaperID=38133>. Accessed: Aug. 31, 2018. doi: 10.1016/j.fcr.2014.08.003.

NRC. The winged bean: A high-protein crop for the tropics. National Academies, 1975.

PEYACHOKNAGUL, S. et al. Sequence and expression of the mRNA encoding the chymotrypsin inhibitor in winged bean (Psophocarpus tetragonolobus). Plant Molecular Biology, v.12, p.51-58, 1989. Available from: <https://link.springer.com/ article/10.1007\%2FBF00017447>. Accessed: Sep. 25, 2018. doi: 10.1007/BF00017447.

PUTZ, F. E.; REDFORD, K. H. The importance of defining 'forest': Tropical forest degradation, deforestation, long-term phase shifts, and further transitions. Biotropica, v.42, p.10-20, 2010. Available from: $<$ https://onlinelibrary.wiley.com/doi/10.1111/j.1744-7429.2009.00567. x>. Accessed: Sep. 25, 2018. doi: 10.1111/j.1744-7429.2009.00567.x.

RAHMAN, M. M. et al. Tropical legume crop rotation and nitrogen fertilizer effects on agronomic and nitrogen efficiency of rice. Scientific World Journal. Available from: $<$ https://www. hindawi.com/journals/tswj/2014/490841/>. Aug. 31, 2018. doi: $10.1155 / 2014 / 490841$.

RIJKERS, T. et al. The effect of tree height and light availability on photosynthetic leaf traits of four neotropical species differing in shade tolerance. Functional Ecology, v.14, p.77-86, 2000. Available from: $<$ https://besjournals.onlinelibrary.wiley.com/doi/1 0.1046/j.1365-2435.2000.00395.x>. Accessed: Apr. 22, 2019. doi: 10.1046/j.1365-2435.2000.00395.x.

SHURTlefF, W.: AOYAGI, A. The Book of Tempeh. Soy Info Center, 1975.

SOMASEGARAN, P.; HOBEN, H. J. Handbook for rhizobia: methods in legume-rhizobium technology. Springer Science \& Business Media, p.135-278, 2012.
STEPHENSON, R. A. et al. Studies on tuber production in winged bean (Psophocarpus tetragonolobus (L.) DC). International Symposium on Tropical Root and Tuber Crops, 1981.

SUMANTA, N. et al. Spectrophotometric analysis of chlorophylls and carotenoids from commonly grown fern species by using various extracting solvents. Research Journal of Chemical Science, v.2231, p.606X, 2014. Available from: $<$ https://www.cabdirect.org/cabdirect/abstract/20153044304>. Accessed: Dec. 2, 2018.

TANZI, A. et al. Development and interaction between plant architecture and yield-related traits in winged bean (Psophocarpus tetragonolobus (L.) DC.). Euphytica, v.215: p.36, 2019. Available from: <https://link.springer.com/ article/10.1007/s10681-019-2359-8>. Accessed: Oct. 30, 2019. doi: $10.1007 / \mathrm{s} 10681-019-2359-8$.

VAN ROEKEL, R. J. et al. Physiological and management factors contributing to soybean potential yield. Field Crop Research, v.182: p.86-97, 2015. Available from: <https://www.sciencedirect. com/science/article/pii/S0378429015001847>. Accessed: Feb. 19, 2019. doi: 10.1016/j.fcr.2015.05.018.

VATANPARAST, M. et al. Transcriptome sequencing and marker development in winged bean (Psophocarpus tetragonolobus; Leguminosae). Scientific Report. v.6, 2016. Available from: $<$ https://www.ncbi.nlm.nih.gov/pmc/articles/PMC4928180/>. Accessed: Nov. 14, 2018. doi: 10.1038/srep29070.

WONG, Q. N., et al. Improving winged bean (Psophocarpus tetragonolobus) productivity: an analysis of the determinants of productivity. Acta Horticulturae, 2015. Available from: <https:// www.actahort.org/books/1102/1102_9.htm>. Accessed: Aug 31, 2018. doi: 10.17660/ActaHortic.2015.1102.9.

WU, H. Effect of different light qualities on growth, pigment content, chlorophyll fluorescence, and antioxidant enzyme activity in the red alga Pyropia haitanensis (Bangiales, Rhodophyta). BioMed Research International, v.7, p.18-26, 2016. Available from: < https://www.hindawi.com/journals/bmri/2016/7383918/>. Accessed: Apr. 22, 2019. doi: 10.1155/2016/7383918.

WU, Y. et al. Responses to shade and subsequent recovery of soya bean in maize-soya bean relay strip intercropping. Plant Production Science, v.19, p.206-214, 2016. Available from: <https://www.tandfonline.com/doi/full/10. 1080/1343943X.2015.1128095>. Accessed: Sep. 25, 2018. doi: $10.1080 / 1343943 X .2015 .1128095$.

ZERVOUDAKIS, G. et al. Influence of light intensity on growth and physiological characteristics of common sage (Salvia officinalis L.). Brazilian Archives of Biology and Technology, v.55(1), p.89-95, 2012. Available from: $<$ http://www.scielo.br/scielo.php? script=sci_arttext\&pid $=$ S1516-89132012000100011 $>$. Accessed: Dec. 2, 2018. doi: 10.1590/S1516-89132012000100011.

ZHU, H., et al. Effects of low light on photosynthetic properties, antioxidant enzyme activity, and anthocyanin accumulation in purple pak-choi (Brassica campestris ssp. Chinensis Makino). PloS One, v.12: e0179305, 2017. Available from: $<$ https://journals. plos.org/plosone/article?id=10.1371/journal.pone.0179305>. Accessed: Apr. 22, 2019. doi: 10.1371/journal.pone.0179305. 